\section{Toxicity effect of sub-chronic oral administration of class bitters $₫$ - a polyherbal formula on serum electrolytes and hematological indices in male Wistar albino rats}

\author{
Kingsley C. Patrick-Iwuanyanwu, \\ Kpobari W. Nkpaa
}

Department of Biochemistry (Toxicology unit), University of Port Harcourt, Rivers State, Nigeria

\begin{abstract}
The indiscriminate administration of readyto-use herbal formulations has become a major concern due to their potential health risk. The study investigated the effect of class bitters ${ }^{\circledR}$ (CB) - a polyherbal formula prepared with Mondia whitei, Khaya senegalensis, Capparis erythrocarpus, Thoningia sanguinea and Xylopia aethiopica on serum electrolytes and hematological parameters in male Wistar albino rats. Two doses (500 and $1000 \mathrm{mg} \mathrm{kg}^{-1}$ ) of the polyherbal drugs were administered orally to male Wistar albino rats for a period of 9 weeks. The results showed that administration of 500 and $1000 \mathrm{mg} \mathrm{kg}^{-1}$ body weight of CB recorded a marked increase in the levels of sodium and chlorum when compared with control. However, there was a marked reduction in the levels of potassium and hydrogen carbonate. The results of the study also showed a significant $(\mathrm{P} \leq 0.05)$ decrease in the level of hematological parameters such as hemoglobin (Hb), packed cell volume (PCV), red blood cells (RBCs) and platelets levels in the male Wistar albino rats, when compared with control. The marked decrease in $\mathrm{Hb}, \mathrm{PCV}, \mathrm{RBCs}$ and platelets concentrations observed in experimental rats in this study suggest that $\mathrm{CB}$ may have an adverse effect on erythropoiesis. These observations therefore showed that long-term administration of CB might cause renal disease and anemia.
\end{abstract}

\section{Introduction}

Herbal medicine is known as botanical medicine which refers to use of plants for medicinal purposes. ${ }^{1}$ Herbal medicines include herbs, herbal materials, herbal preparations and finished herbal products that contain parts of plants or other plant materials as active ingredients. It is still the mainstay of about $75-80 \%$ of the world population, mainly in the develop- ing countries, for primary health care because of better cultural acceptability, better compatibility with the human body and lesser side effects. $^{2}$

The World Health Organization (WHO) has recently defined traditional medicine (including herbal drugs) as comprising therapeutic practices that have been in existence, often for hundreds of years, before the development and spread of modern medicine and are still in use today. ${ }^{3}$ Traditional medicine is the synthesis of therapeutic experience of generations of practicing physicians of indigenous systems of medicine. The traditional preparations comprise medicinal plants, minerals, organic matter, etc. Herbal drugs constitute only those traditional medicines, which primarily use medicinal plant preparations for therapy. ${ }^{2}$

Herbal medicines have gained popularity as a natural approach for treatment of varying conditions or illness. It is a form of alternative medicine that includes use of different plant and plant extracts for treatment of diseases. Man has practiced their use for treatment of diseases for many years and it has become widely used as alternative medicines. ${ }^{4}$ In Nigeria today, herbal remedies are selling even more than the synthetic drugs. Consumers prefer these formulas due to easy accessibility (less expensive), and claims that they have fewer side effects since they are natural products. Herbal medicinal products are unlikely to pose a significant threat to human health; nonetheless, it is important to validate their safety. The confidence in herbal medicines is backed by their long-term usage. Validation of their safety is necessary because crude herbal medicines are given in most cases without accurate dosage and over ingestion can result in toxicity. ${ }^{5}$ It is also possible for the plant to have silent toxic effect that may not be evident within a short time. ${ }^{6}$ The use of herbal medicinal products may present potential risk to human health, ${ }^{7}$ but some toxic herbal medicines have been proven to have beneficial effects at very low doses. ${ }^{6}$ To protect public health, it is necessary to ensure that all medicines, including unlicensed products, are safe for human consumption and of suitable quality. Herbal medicines are required to meet the same safety, quality and efficacy criteria as any other licensed medicine. Serious liver toxicity has been reported to be associated with the use of some herbal medicines. ${ }^{5}$ Recent research revealed that adverse reactions to herbal products are under-reported. ${ }^{8}$ The more subtle and chronic forms of toxicity, such as carcinogenicity, mutagenicity, and hepatotoxicity, may well have been overlooked by previous generations and it is these types of toxicity that are of most concern when assessing the safety of herbal remedies. ${ }^{9}$

The root of Mondia whitei is traditionally used in the treatment of urinary tract infec-
Correspondence: Kpobari W. Nkpaa, Department of Biochemistry (Toxicology unit), Faculty of Chemical and Biological Sciences, College of Natural and Applied Sciences, University of Port Harcourt, P.M.B 5323, Choba, Port Harcourt, Rivers State, Nigeria.

Tel.: +2348066626323

E-mail: nkwilly@gmail.com

Key words: Class bitters®; nephrotoxicity; hematological parameters; herbal remedy; medicinal plant.

Contributions: this work was carried out in collaboration between the two authors. Author KCPI designed the study, wrote the protocol, collected all data, managed the analyses of the study and performed the statistical analysis. KWN wrote the first draft of the manuscript, managed the literature searches and managed the animals. All authors read and approved the final manuscript.

Conflict of interest: the authors declare no conflict of interest.

Received for publication: 15 June 2015 .

Revision received: 2 November 2015.

Accepted for publication: 2 November 2015.

This work is licensed under a Creative Commons Attribution NonCommercial 3.0 License (CC BYNC 3.0).

(C) Copyright K.C. Patrick-Iwuanyanwu and K.W. Nkpaa, 2015

Licensee PAGEPress, Italy

Journal of Xenobiotics 2015; 5:5369

doi:10.4081/xeno.2015.5369

tion, headache, jaundice while the whole plant is used to treat diarrhea. ${ }^{10,11}$ The aqueous extracts and root have also been reported to be an efficacious aphrodisiac for the treatment of male impotence. ${ }^{12}$ Khaya senegalensis on the other hand has been reported to exhibit antiinflammatory effects,${ }^{13}$ treatment of jaundice, dermatose, diarrhea and venereal diseases and hookworm infection. ${ }^{14,15}$ The seed and juice of pounded leaves of Capparis erythrocarpus are used against child convulsive fever and the pounded root is used in severe abscess while in Tanzania and India, the pounded root is used for the treatment of inflammation of the connective tissue of the eye. ${ }^{16,17}$ Xylopia aethiopica is commonly administered after child birth to arrest bleeding owing to his antiseptic properties. ${ }^{18}$ It has also been reported to be an antioxidant; ${ }^{19}$ anti-hypertensive and diuretic effects ${ }^{20}$ and hepatoprotective. ${ }^{21}$ Limited toxicological data are available on medicinal plants. Class bitters ${ }^{\circledR}$ (CB) is a polyherbal formula produced by Classic Herbal Centre in Accra, Ghana. Ethnomedicinally, CB is taken three times daily for the treatment of diabetes mellitus, muscle pains, joint pains, backache, general body pains and sexual weak- 
ness. ${ }^{22}$ This present study was carried out to investigate the toxicity effect of $\mathrm{CB}$ - a polyherbal formula on serum electrolytes and hematological indices of male Wistar albino rats.

\section{Materials and Methods}

\section{Herbal sample}

Five bottles of $\mathrm{CB}$ with the same batch number $\mathrm{Bx} / 04 / 10$ produced by Classic Herbal Centre, Accra, Ghana, where use in these study. They were purchased from a local herbal drug retailer in Rumuola, Port Harcourt, Rivers State, Nigeria.

\section{Experimental animals}

A total of 30 male Wistar albino rats weighing between 140 to $160 \mathrm{~g}$ used in this study were obtained from the Animal House of the Department of Biochemistry, University of Port Harcourt, Choba, Rivers State, Nigeria. The animals were kept singly in a cross-ventilated house and were fed with standard rat pellet and water ad libitum. The rats were acclimatized for 7 days. The experiment was performed after the experimental protocol was approved by the Institutional Animal Ethics Committee.

\section{Acute toxicity test}

Healthy male Wistar albino rats weighing between 140-160 g maintained under standard laboratory conditions were used for acute toxicity test according to the Organization for Economic Cooperation and Development (OECD) guidelines 425 (OECD 2000 guidelines). A total of ten animals were used which received a single oral-dose of $2000 \mathrm{mg} / \mathrm{kg}$ body weight (b.w.) of CB. Animals were kept overnight fasting prior to drug administration by oral gavage. After administration of drug sample, food was withheld for further 3-4 h. animals were observed individually at least once during first $30 \mathrm{~min}$ after dosing, periodically during first $24 \mathrm{~h}$ (with special attention during the first $4 \mathrm{~h}$ ) and daily thereafter for a period of 14 days. Daily observation on the changes of skin and fur, eyes and mucus membrane (nasal), respiratory rate, circulatory signs (heart rate and blood pressure), autonomic effects (salivation, lacrimation, perspiration, piloerection, urinary incontinence and defecation) and central nervous system (ptosis, drowsiness, gait, tremors and convulsion changes were noted. ${ }^{23}$

\section{Subchronic oral toxicity study}

Thirty male Wistar albino rats were divided into three groups of 10 rats per group. Group 1 served as the control and received standard feed and distilled water only. Groups 2 and 3 received standard feed, distilled water and $\mathrm{CB}$ at doses of 500 and $1000 \mathrm{mg} \mathrm{kg}^{-1}$ b.w. respectively. ${ }^{24}$ Administration of the extract was done orally by means of a polythene cannula. Animals received their doses once a day for 9 weeks. They were observed daily for clinical signs of toxicity or pharmacological signs, throughout the period of study.

\section{Samples collection}

At the end of the treatment period, the animals were weighed and sacrificed using cervical dislocation method. Blood samples were obtained by cardiac puncture using $2 \mathrm{~mL}$ hypodermal syringe. The blood samples were introduced into clean dry anti-coagulant free bottles. The anti-coagulant free bottles containing the sample were centrifuged at $3000 \mathrm{rpm}$ for 10 min to separate serum from packed cells, the serum obtained was collected into a clean dry sample bottle and used for the analysis of sodium, potassium, chloride and bicarbonate while the blood samples for hematological studies were collected into clean dry sample bottle containing ethylenediaminetetraacetic acid anticoagulant with the aim of preventing coagulation. White blood cell (WBC) count, lymphocytes, neutrophil, mean corpuscular hemoglobin concentration (MCHC) and mean corpuscular hemoglobin (MCH) were estimated using a fully automated hematology analyzer. The auto counter utilized $20 \mu \mathrm{L}$ of blood in 4.5 $\mathrm{mL}$ of a commercially prepared diluent.

\section{Statistical analysis}

Values are expressed as means \pm standard error of mean. The results were analyzed statistically by analysis of variance (ANOVA) followed by Turkey multiple comparison test. Significance was accepted at a P-value of 0.05 .

\section{Results}

The result of the acute toxicity showed no mortality or physical changes in skin and fur, eyes and mucus membrane (nasal), respiratory rate, circulatory signs (heart rate and blood pressure), autonomic effects (salivation, lacrimation, perspiration, piloerection, urinary incontinence and defecation) and central nervous system (ptosis, drowsiness, gait, tremors and convulsion) among rats administered $2000 \mathrm{mg} \mathrm{kg}^{-1}$ b.w. of CB. Since none of the mentioned toxic signs and symptoms or mortality was observed in the animals at the above mentioned dose, 500 and $1000 \mathrm{mg} \mathrm{kg}^{-1}$ b.w. of test drug were selected for the study. The results of the effect of oral administration of CB on serum electrolyte are showed in Table 1. Results from the study showed that adminis- tration of 500 and $1000 \mathrm{mg} \mathrm{kg}{ }^{-1}$ b.w. of CB recorded a marked increase in the levels of sodium $\left(\mathrm{Na}^{+}\right)$and chlorum $\left(\mathrm{Cl}^{-}\right)$when compared with control. However, potassium $\left(\mathrm{K}^{+}\right)$ and hydrogen carbonate $\left(\mathrm{HCO}_{3}^{-}\right)$levels showed a marked reduction when compared with the control. In this present study, the results of the effects of $\mathrm{CB}$ on hematological parameters are shown in Tables 2 and 3 . Results of the study showed that administration of 500 and $1000 \mathrm{mg} \mathrm{kg}^{-1}$ b.w. of CB recorded a significant $(\mathrm{P} \leq 0.05)$ decrease in the levels of hemoglobin ( $\mathrm{Hb})$, packed cell volume (PCV), red blood cells (RBCs), WBC, neutrophil and platelets when compared with control with the experimental rats in the group administered with $1000 \mathrm{mg} \mathrm{kg}^{-1}$ having the lowest hematological parameters level. However, the mean concentration of $\mathrm{MCH}$ and MCHC administered with 500 and $1000 \mathrm{mg} \mathrm{kg}^{-1}$ b.w. of CB did not show any significant $(\mathrm{P} \leq 0.05)$ difference as compared to the control. The result obtained from the study also showed that lymphocyte count as observed in the study in rats administered $1000 \mathrm{mg} \mathrm{kg}-1$ b.w. of CB significantly $(\mathrm{P} \leq 0.05)$ increased as compared to the control.

\section{Discussion and Conclusions}

Toxicity studies of herbal drugs in animals are commonly used to assess potential health risk in humans, caused by intrinsic adverse effects of chemical compounds or plant extracts. ${ }^{25}$ The deleterious effects of these extracts may be accompanied or preceded by clinical signs of toxicity such as salivation, loss of hair, changes in animal eye color, decreased respiratory rate and motor activity. The various biochemical parameters investigated in this study are useful indices that can be employed to assess the toxic potentials of plant extracts/botanicals in living systems. ${ }^{26}$ Such toxicity testing is relevant to risk evaluation as changes in the hematological system have higher predictive value for human toxicity, when data are translated from animal studies. ${ }^{27}$

The study investigated the effect of $\mathrm{CB}$ on serum electrolytes $\left(\mathrm{Na}^{+}, \mathrm{Cl}^{-}, \mathrm{K}^{+}\right.$and $\left.\mathrm{HCO}_{3}^{-}\right)$in male Wistar albino rats. CB is a polyherbal formula, which is commonly used in the treatment of muscle pain, joint pains, hypertension, stroke and anemia. Electrolytes are basically ions that conduct electricity in the body. The increase in the concentration of $\mathrm{Na}^{+}$observed in rats administered 500 and $1000 \mathrm{mg} \mathrm{kg}^{-1}$ b.w. may have been as a result of sodium retention due to intrinsic renal disease or inadequate renal perfusion..$^{28}$ The reduction in the concentration of $\mathrm{K}^{+}$in the group administered $500 \mathrm{mg}$ $\mathrm{kg}^{-1}$ may be an indication of hypokalemia or severe depletion of potassium - showing kidney disease. ${ }^{29}$ Potassium is the principal 
cation of intracellular fluids which is required for steady heartbeat. It has been reported that a decrease in potassium ion concentration in the cell causes muscles weakness which eventually leads to cardiac problems. ${ }^{30}$ An increase in the concentration of $\mathrm{Cl}^{-}$in the group administered $1000 \mathrm{mg} \mathrm{kg}^{-1} \mathrm{CB}$ may be a sign of metabolic acidosis. On the other hand, a reduction in the concentration of $\mathrm{HCO}_{3}{ }^{-}$in groups administered 500 and $1000 \mathrm{mg} \mathrm{kg}^{-1}$ b.w. CB is suggestive that the blood $\mathrm{pH}$ is acidic and could lead to the condition known, as acidemia. ${ }^{28}$ Bicarbonate buffer system is the most important amongst blood buffers when the $\mathrm{pH}$ of the blood is considered..$^{31}$ Reduction in serum bicarbonates implies that the $\mathrm{pH}$ of the blood was lowered. This reduction may be attributed to two mechanisms: excessive respiratory excretion via hyperventilation, or increased renal excretion of bicarbonates. ${ }^{32}$ Bicarbonate is an extracellular anion found in the blood which reflects acute changes in acidbase balance.

The observation of a reduction in the levels of $\mathrm{Hb}, \mathrm{PCV}, \mathrm{RBC}$ and platelets in male Wistar albino rats is suggestive that $\mathrm{CB}$ can directly or in directly or both destroy RBCs and lower the hemoglobin concentration. The indirect effects may be as a result of oxidative damage. It has been reported that when malonaldehyde is released in the tissues, it may destroy $\mathrm{RBC}$ and reduced erythrocytes survival. ${ }^{33}$ Changes in hematological parameters such as $\mathrm{Hb}$, PCV,
$\mathrm{RBC}$ and platelets are routinely used to determine stress associated with environmental, nutritional and pathological factors.

Other hematological parameters namely: $\mathrm{MCH}, \mathrm{MCHC}$ and MCV relates to individual red blood cells while $\mathrm{Hb}, \mathrm{RBC}$ and PCV are associated with the total population of red blood cells. ${ }^{34}$ The significant effect of CB on RBCs might be an indication that the balance between the rate of production and destruction of the blood corpuscles (erythropoiesis) was altered. That is, the significant $(P \leq 0.05)$ decrease in the red blood cell and hemoglobin may have resulted from the suppression of circulating hormone, erythropoietin (a glycoprotein which stimulates the process of erythropoiesis).$^{35}$ Reduction in blood concentration of erythropoietin may result in a normochromic, normocytic anaemia. ${ }^{36}$ Reduction in platelets count in experimental animals has been reported to indicate adverse effect on the oxygen- carrying capacity of the blood as well as thrombopoietin. ${ }^{37}$ Results from this study show that the platelet count was significantly $(\mathrm{P} \leq 0.05)$ altered signifying that the oxygen carrying capacity of the blood was affected when $\mathrm{CB}$ was administered at a dose of 500 and $1000 \mathrm{mg} \mathrm{kg}^{-1}$ b.w. to the male Wistar rats. The MCV is an index of the size of the RBCs. When the MCV is below normal, the RBCs will be smaller than normal and are described as microcytic. ${ }^{38}$ When the MCV is elevated, the RBCs will be larger than normal and are termed macrocytic. RBCs of normal size are termed normocytic. ${ }^{39}$ These size categories are used to classify anaemias..$^{38}$ In this study, the RBC was below normal. When the RBC count is low, the body is not able to get as much oxygen to go throughout the bodies, which may result to anemia. CB also significantly increased bilirubin level in our previous study; these increased could lead to hemolytic anemia. ${ }^{22}$ Conclusively, the abusive use of herbal remedies for various ailments should be put in check. Data from this study suggest that prolonged use of CB may have adverse effects on hematological indices and serum electrolytes. It is therefore; recommend that further studies be carried out at cellular and molecular levels in order to ascertain the toxicity potentials of CB.

\section{Research highlights}

This study investigated the effect of class bitters ${ }^{\circledR}$ - a polyherbal formula on serum electrolytes and hematological parameters in male Wistar albino rats. Administration of 500 and $1000 \mathrm{mg} \mathrm{kg}^{-1}$ body weight (b.w.) of $\mathrm{CB}$ recorded a marked decrease in $\mathrm{Hb}, \mathrm{PCV}, \mathrm{RBC}$ and platelets concentrations. This study suggests that CB may have an adverse effect on erythropoiesis. Long-term administration may cause renal disease and anemia.

Table 1. Effect of oral administration of class bitters ${ }^{\circledR}$ on serum electrolytes.

\begin{tabular}{|c|c|c|c|c|}
\hline $\begin{array}{l}\text { CB Conc. } \\
\left(\mathrm{mg} \mathrm{kg}^{-1}\right)\end{array}$ & $\begin{array}{c}\mathrm{Na}^{+} \\
(\mathrm{mMol} / \mathrm{L})\end{array}$ & $\begin{array}{c}\mathrm{K}^{+} \\
(\mathrm{mMol} / \mathrm{L})\end{array}$ & $\begin{array}{c}\mathrm{Cl}^{-} \\
(\mathrm{mMol} / \mathrm{L})\end{array}$ & $\begin{array}{c}\mathrm{HCO}_{3}^{-} \\
(\mathrm{mMol} / \mathrm{L})\end{array}$ \\
\hline Control & $153.00 \pm 5.66$ & $10.07 \pm 0.80$ & $113.6 \pm 8.78$ & $16.50 \pm 2.04$ \\
\hline 500 & $156.83 \pm 8.18^{a}$ & $8.25 \pm 0.98^{a}$ & $112.05 \pm 5.38$ & $12.87 \pm 3.66^{\mathrm{a}}$ \\
\hline 1000 & $155.83 \pm 8.33$ & $9.53 \pm 1.35^{\mathrm{a}}$ & $116.0 \pm 6.67^{\mathrm{a}}$ & $13.90 \pm 3.70^{\mathrm{a}}$ \\
\hline
\end{tabular}

$\mathrm{CB}$, class bitters ${ }^{\circledR}$; Conc., concentration; $\mathrm{Na}^{+}$, sodium; $\mathrm{K}^{+}$, potassium; $\mathrm{Cl}^{-}$, chlorum; $\mathrm{HCO}_{3}{ }^{-}$, hydrogen carbonate. Values are mean \pm standard deviation, (n=10); values with superscripts are significantly different at $\mathrm{P} \leq 0.05$.

Table 2. Effect of oral administration of class bitters ${ }^{\circledR}$ on hematological parameters.

\begin{tabular}{lccc} 
CB Conc. $\left(\mathrm{mg} \mathrm{kg}^{-1}\right)$ & Plb $(\mathrm{g} / \mathrm{dL})$ & RBC (10\% $/$ Platelets \\
Control & $17.13 \pm 2.070$ & $10.11 \pm 1.546$ & $57.767 \pm 3.471$ \\
500 & $14.58 \pm 1.21^{\mathrm{a}}$ & $6.96 \pm 1.75^{\mathrm{a}}$ & $45.58 \pm 2.83^{\mathrm{a}}$ \\
\hline 1000 & $10.00 \pm 1.52^{\mathrm{a}}$ & $6.45 \pm 0.92^{\mathrm{a}}$ & $43.85 \pm 8.36^{\mathrm{a}}$ \\
\hline
\end{tabular}

$\mathrm{CB}$, class bitters®; Conc., concentration; Hb, hemoglobin; $\mathrm{PCV}$, packed cell volume; $\mathrm{RBC}$, red blood cells count. Values are mean \pm standard deviation, ( $\mathrm{n}=10$ ); values with superscripts are significantly different at $\mathrm{P} \leq 0.05$.

Table 3. Effect of oral administration of class bitters ${ }^{\circledR}$ on hematological parameters.

\begin{tabular}{|c|c|c|c|c|c|}
\hline CB Conc. (mg kg-1) & WBC $\left(10^{3} / \mu \mathrm{L}\right)$ & MCH (g/L) & MCHC (g/L) & Neutrophil (\%) & Lymphocyte (\%) \\
\hline Control & $17.01 \pm 1.01$ & $19.88 \pm 1.38$ & $34.48 \pm 1.40$ & $13.45 \pm 1.78$ & $72.73 \pm 1.81$ \\
\hline 500 & $10.9 \pm 1.98^{a}$ & $19.4 \pm 1.51$ & $33.7 \pm 1.51$ & $11.88 \pm 1.94^{\mathrm{a}}$ & $72.43 \pm 3.46$ \\
\hline 1000 & $8.02 \pm 1.75^{\mathrm{a}}$ & $18.7 \pm 0.43$ & $35.4 \pm 0.87$ & $10.47 \pm 1.18^{a}$ & $80.23 \pm 7.12^{a}$ \\
\hline
\end{tabular}

$\mathrm{CB}$, class bitters ${ }^{\circledR}$; Conc., concentration; $\mathrm{WBC}$, whit blood cells count; $\mathrm{MCH}$, mean corpuscular hemoglobin; $\mathrm{MCHC}$, mean corpuscular hemoglobin concentration. Values are mean \pm standard deviation, ( $\mathrm{n}=10$ ); values with superscripts are significantly different at $\mathrm{P} \leq 0.05$. 


\section{References}

1. Bright JJ. Curcumin and autoimmune disease. Adv Exp Med Biol 2007;595:425-51.

2. Kamboj VP. Herbal medicine. Curr Sci 2000;78:1-17.

3. Fahn A. Plant anatomy. 3rd ed. Oxford: Pergamon Press; 1989.

4. Kokwaro J0. Medicinal plants of East Africa. 2nd ed. Nairobi: Kenya Literature Bureau; 1993.

5. Sunday 00, Uguru M0, Ochigbo EA. The effect of aqueous extracts on Momordica balsamina on haematological and biochemical parameters in rats. Asian $\mathrm{J}$ Pharm Clin Res 2009;2:21-5.

6. Medicines Control Agency (MCA). Safety of herbal medicinal products; July 2002. Available from: https://hfnet.nih.go.jp/usr/ kiso/ninpu-herb/HerbalsSafety ReportJuly 2002_Final.pdf

7. De Smet PAGM. Health risk of herbal remedies. Drug Safety 1995;13:81-93.

8. Barnes J, Mills SY, Abbot NC, Willoughby M, Ernst E.. Different standards for reporting ADRs to herbal remedies and conventional OTC medicines: face to face interviews with 515 users of herbal remedies. Br J Clin Pharmacol 1998;45:496-500.

9. Shaw D, Leon C, Kolev S, Murray V. Traditional remedies and food supplements: a 5-year toxicological study (19911995). Drug Safety 1997;17:342-56.

10. Adjanahoun JE, Aboubakar N, Dramane K, Ebot ME, Ekpere JA, Enow-Orock EJ, et al. Traditional medicine and pharmacopoeia: contribution to ethnobotanical and floristic studies in Cameroon. Yaoundé: Organization of African Unity (OAU)/ Scientific, Technical, and Research Commission (STRC); 1996. pp 224-315.

11. Noumi E, Amvam ZPH, Lontsi D. Aphrodisiac plants used in Cameroon. Fitoterapia 1998;69:125-34.

12. Lampiao F. The role of Mondia whitei in reproduction: a review of current evidence. Internet $\mathrm{J}$ Third World Med 2009;8:(1).

13. Lompo M, Nikiema JB, Guissou IP, Moes AJ Fontaine J. The topical anti-inflammatory effect of chloroform extracts from Khaya senegalensis stembarks. Phytother Res 1998;12:448-50.

14. Iwu M. Hankbook of African medicinal plants, pharmacognostical profile of selected medicinal plants. Boca Raton, FL: CRC Press Inc.; 1993.

15. Gills LS. Ethnomedical uses of plants in Nigeria. Benin City: University of Benin press; 1992. pp 276.

16. Hedberg I, Hedberg 0, Madati PJ, Mshigeni KE, Mshiu EN, Sumuelson G. Inventory of plants used in traditional medicine in Tanzania. 1. Plants of the families Acanthaceae-Cucurbitaceae. J Ethnopharmacol 1982;6:29-60.

17. Martey ONK, Armah GE, Sittie AA, Okine LKN. A chronic toxicity study of the ground root bark of Capparis erythrocarpus (Capparecceae) in malw Sprague-dewley rat. Pak J Biol Sci 2013;16:1706-13.

18. Burkhills HM. Useful plants of West Tropical Africa. 2nd ed. Royal Botan Garden 1985;1:130-2.

19. Amayaw Y, Owusu-Ansah E. Morphohistological studies of two plants species used in ethnomedicine. J Herbs Spices Med Plants 1998;5:60-85.

20. Somova LL, Shode F0, Moodley K, Govender Y. Cardiovascular and diuretic activity of kaurene derivatives of Xylopia aethiopica and Alepidea amatymbica. J Ethnopharmacol 2001;77:165-74.

21. Patrick-Iwuanyanwu KC, Wegwu MO, Okiyi JK. Hepatoprotective effects of African Loust Bean (Parkia clappertoniana) and Negro Pepper (Xylopia aethiopica) in CCl4-Induced Liver damage in Wistar Albino rats. Int $\mathbf{J}$ Pharmacol 2010;6:744-9.

22. Patrick-Iwaunyanwu KC, Chinaka DE, Gboelo BB. Evaluation of acute and subchronic toxicities of class bitters; a polyherbal formula in male albino rats. Pharmacologia 2012;3:707-12.

23. Organization for Economic Co-operation and Development (OECD). Guidelines for the testing of chemicals. Paris: OECD; 2000.

24. Chandra P, Sachan N, Ghosh AK, Kishore K. Acute and Sub-chronic oral toxicity studies of a mineralo-herbal drug amlene on experimental rats. Int $\mathrm{J}$ Pharm Res 2010;1:15-8.

25. Ashafa AT, Olunu 00. Toxicological evaluation of ethanolic root extract of Morinda lucida (L.) Benth. (Rubiaceae) in male Wistar rats. J Nat Pharm 2011;2:108-14.

26. Sunmonu T0, Oloyede OB. Performance and haematological indices in rats exposed to monocrotophos contamination. Hum Exp Toxicol 2010;29:845-50.

27. Olson H, Betton G, Robinson D, Thomas K,
Monro A, Kolaja G, et al. Concordance of toxicity of pharmaceuticals in humans and in animals. Regul Toxicol Pharmacol 2000;32:56-67.

28. Ochie J, Kolhatkar A. Medical laboratory science: theory and practice. New Delhi: Tata McGraw-Hill Publishing Company Ltd.; 2008. pp 1-1338.

29. Kratz A, Ferraro M, Sluss PM, Lewandrowski KB, Ellender SM, Peters CC, et al. Case records of the Massachusetts General Hospital. Weekly clinicopathological exercises. Laboratory reference values. N Engl J Med 2004;351:1548-63.

30. Chauhan V, Kelepouris E, Chauhan N, Vaid M. Current concepts and management strategies in chronic kidney disease-mineral and bone disorder. Southern Med J 2012;105;479-85.

31. Mount DB, Zandi-Nejad K. Disorders of potassium balance. In: Brenner BM, ed. Brenner and Rector's The Kidney. 8th ed. Philadelphia, PA: Elsevier Saunders; 2008. pp 15.

32. Shirley DG, Capasso G, Unwin RJ. Renal physiology. In: Johnson R, Feehally J, eds. Principles of clinical nephrology. 2nd ed. Philadelphia, PA: Mosby International; 2003. pp 21-30.

33. Draper HH, Polensek I, Hadley M, Mcgirr IG. Urinary malondialdehyde as an indicator of lipid peroxidation in the diet and in the tissues. Lipids 1988;19:836-43.

34. Ashafa AT, Sunmonu TO, Afolayan AJ. Effects of leaf and berry extracts of Phytolacca dioica L. on haematological and weight parameters of Wistar rats. Afr $\mathrm{J}$ Pharm Pharmacol 2011;5:150-4.

35. Guyton CA, Hall JE. Textbook of medical physiology. 10th ed. London: W.B Saunders Co.; 2000. pp 264, 382, 389, 730-731, 797802.

36. Kumar P, Clark M. Clinical medicine. 5th ed. London: W.B Saunders Co.; 2003. pp 592.

37. McLellan SA, McLellan DBL, Walsh TS. Anaemia and red blood cell transfusion in the critically ill patient. Blood Rev 2003;17:195-208.

38. Iniaghe OM, Egharevba 0, Oyewo EB. Effect of aqueous leaf extract of Acalypha wilkesiana on hematological parameters in male Wistar albino rats. Br J Pharm Res 2013;3:465-71.

39. Chernecky CC, Berger BJ. Laboratory tests and diagnostic procedures, 3rd ed. Philadelphia, PA:W. B. Saunders Co.; 2001. 